\title{
PETROLOGIA DOS GRANITOS DA SERRA DA PEDRA BRANCA, RIO DE JANEIRO, RJ, BRASIL
}

\author{
R.Porto Jr. ${ }^{1}$, M.C.H.Figueiredo (in memorian) ${ }^{2}$
}

\begin{abstract}
O Complexo Granítico Pedra Branca (CGPB) representa um corpo intrusivo de composição predominantemente granítica com área de $150 \mathrm{~km}^{2}$, situado na porção centro-oeste da cidade do Rio de Janeiro. Estudos de campo, petrográficos e geoquímicos recentes realizados na região apontaram para a presença de três Unidades litológicas: Unidade Tonalítica, Unidade Granito Pedra Branca e Unidade Biotita Granito (Porto Jr., 1994). As rochas encaixantes compreendem uma sequência basal composta de ortognaisses migmatíticos (dioríticos a granodioríticos) e uma seqüência de topo com paragnaisses (kinzigitos, plagioclásio gnaisse e leptinitos). A Unidade Tonalítica (UTn) é formada por litotipos de composição básica a intermediária (gabro, diorito, quartzo diorito, tonalito e granodiorito) foliados ou não. A Unidade Granito Pedra Branca (UGPB) é dominante em área e formada por um sieno a monzogranito rico em megacristais de microclina. Quatro fácies foram individualizadas na UGPB. A fácies médiahomogênea, dominante em área, exibe grande homogeneidade textural apresentando cristais de microclina pertítica de até $2 \mathrm{~cm}$. A fácies bandada é individualizada pela presença de megacristais de microclina de até $7 \mathrm{~cm}$ e filmes de biotita, e é entendida como produto da composição de tensão diapírica com esforços regionais persistentes durante o posicionamento da intrusão. A fácies pegmatítica ocorre como bolsões ou diques subconcordantes às estruturas das encaixantes e é formada por $70 \%$ de megacristais de microclina de até $12 \mathrm{~cm}$. A fácies hololeucocrática ocorre como bandas espetacularmente bem definidas, homogêneas e interestratificadas à fácies média-homogênea. Os contatos entre as várias fácies são gradacionais, com exceção daqueles entre as fácies média-homogênea e hololeucocrática. Os contatos da UGPB com as rochas da UTn são intrusivos e marcados pela presença de xenólitos da UTn na UGPB. A Unidade Biotita Granito (UBg) aflora sob a forma de diques sub-horizontais pouco espessos de estruturação complexa. Duas fácies puderam ser individualizadas: uma porfirítica, de borda, com estrutura de fluxo e enclaves xenolíticos e microgranulares; e outra equigranular, coincidente com as partes mais internas das intrusões. Trata-se de um monzogranito de cor cinza e equigranular.
\end{abstract}

As rochas do CGPB pertencem a um magmatismo subalcalino, de evolução calcioalcalina. Pequenos volumes ou ausência de córidon normativo apontam para um caráter metaluminoso. Há ampla variação no conteúdo de $\mathrm{SiO}_{2}$, com gaps composicionais definidos nos intervalos entre 64 e $68 \%$ e 72 e $75 \%$, que correspondem, respectivamente, à separação das rochas da UTn das demais e à individualização da fácies hololeucocrática. Dados de campo aliados aos gaps composicionais e à separação apresentada em diagrama R1 x R2 definem a presença de, pelo menos, duas séries calcioalcalinas distintas, caracterizando a ausência de cogeneticidade entre as rochas da UTn e as demais. Com base nestes dados, a interpretação tectônica aponta para um ambiente compressivo, tendo os litotipos da UTn um posicionamento

\footnotetext{
${ }^{1}$ Setor de Petrologia e Mapeamento, DG/IA, Universidade Federal do Rio de Janeiro.

${ }^{2}$ DGG, Instituto de Geociências, Universidade de São Paulo.
} 
sin-tectônico, e os demais, posicionamento tardi-tectônico (UGPB) e francamente pós-tectônico (UBg). Dados de ETR mostram um enriquecimento em ETRl que vem sendo interpretado como indicador característico do aumento da maturidade do arco durante a evolução da intrusão. Qualquer modelo petrogenético para estas rochas deve levar em consideração os seguintes aspectos: 1- grande quantidade de rochas ácidas e ausência de cumulados ou rochas básicas que sugerissem fracionamınto a partir de magma básico; 2- presença de enclaves arredondados, dioríticos a quartzo dioríticos; 3- ausência de zonalidade magmática; e 4- contatos gradacionais entre as fácies definidas para o UGPB. Fusão parcial na base da crosta é o modelo mais adequado para explicar a origem do magma que gerou a UTn. O comportamento desta Unidade em diagrama R1 x R2 favorece tal hipótese. A pequena diversidade de litotipos encontrados no UGPB, sua complexidade estrutural e os fatores supracitados apontam para a atuação de mecanismos de evolução como: 1- fusão parcial de rochas ortoderivadas na base da crosta; 2"desmistura"; e 3- cristalização fracionada in situ. $\mathbf{O}$ grande volume de rochas ácidas, a rara ocorrência de rochas básicas ou cumulados e a ausência de anomalias negativas em Eu desfavorecem a derivação a partir de magma básico. A presença de enclaves microgranulares, restitos e diques sin-plutônicos nas rochas das UGPB e UBg indicam que segregações ou pulsos de magma básico ocorreram durante a evolução do magmatismo ácido. Os líquidos graníticos podem ter sido gerados na crosta inferior, como produtos de diferentes graus de fusão de uma mesma rocha fonte. Grandes volumes de fusão parcial da crosta inferior envolve provavelmente a formação de crystal mush, gerando feições características dos granitos da UGPB. Em diagrama R1 x R2, as rochas graníticas concentram-se no campo dos granitos gerados por fusão crustal, podendo ter predominado processo de desmistura como mecanismo de evolução. Entretanto, a existência de contatos gradacionais entre as fácies da UGPB, a ocorrência de cumulados feldspáticos (fácies pegmatítica) e segregações de plagioclásio e K-feldspato (fácies hololeucocrática) sugerem fortemente a atuação de processo de cristalização fracionada durante a evolução do magma granítico. A pequena variação de $\mathrm{Al}_{2} \mathrm{O}_{3}$ e $\mathrm{Na}_{2} \mathrm{O}$ e a correlação positiva entre $\mathrm{K}_{2} \mathrm{O}$ e $\mathrm{Si}_{2} \mathrm{O}$ apontam para o fracionamento de plagioclásio. Porém, o conteúdo elevado de $\mathrm{Ba}$ e $\mathrm{Sr}$ e a presença de anomalias negativas discretas e até positivas em Eu indicam que este fracionamento foi limitado. Ausência de zonalidade no CGPB também limita o processo de cristalização fracionada, devendo este ter ocorrido in situ, após a colocação do diápiro. 0 processo e a fonte geradora do magma da UBg devem ser considerados semelhantes aos da UGPB, com a diferença de que, no momento da extração do magma da UBg, a fonte já se encontrava empobrecida, em função da extração de extensos volumes de magma representados pela UGPB. A ausência de material de origem cumulítica indica, que o fracionamento não ocorreu por continua e eficiente remoção de cristais do líquido, o que levaria à formação de uma intrusão zonada. Entretanto, a presença de cristais zonados com bordas de reação aponta para a atuação de cristalização fracionada in situ através de mecanismo de lenta difusão iônica intracristalina, quando comparada à razão de cristalização.

\section{Referência Bibliográfica}

PORTO JR., R. (1994) Petrologia das Rochas Graníticas das Serras da Pedra Branca e Misericórdia, Município do Rio de Janeiro, RJ, Brasil. Rio de Janeiro, 240p. (Dissertação - Mestrado) - Instituto de Geociências, Universidade Federal Rio de Janeiro. 